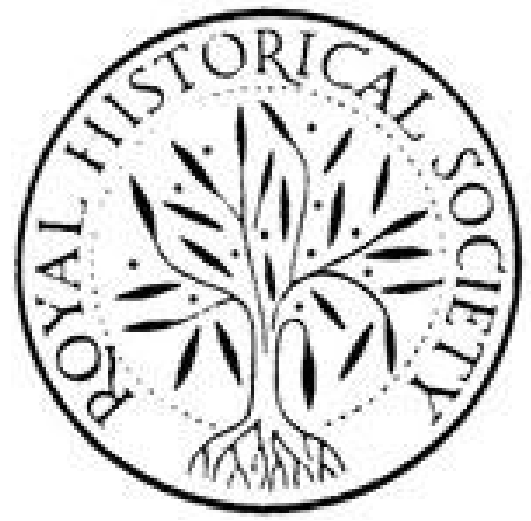

Historical Notes on the Education of the Deaf Author(s): B. St. John Ackers

Source: Transactions of the Royal Historical Society, Vol. 8 (1880), pp. 163-171 Published by: Cambridge University Press on behalf of the Royal Historical Society Stable URL: http://www.jstor.org/stable/3677827

Accessed: 27-06-2016 02:54 UTC

Your use of the JSTOR archive indicates your acceptance of the Terms \& Conditions of Use, available at

http://about.jstor.org/terms

JSTOR is a not-for-profit service that helps scholars, researchers, and students discover, use, and build upon a wide range of content in a trusted digital archive. We use information technology and tools to increase productivity and facilitate new forms of scholarship. For more information about JSTOR, please contact support@jstor.org.

Cambridge University Press, Royal Historical Society are collaborating with JSTOR to digitize, preserve and extend access to Transactions of the Royal Historical Society 


\title{
HISTORICAL NOTES ON THE EDUCATION OF THE DEAF.
}

\author{
By B. St. JOHN ACKERS, Esq., \\ Fellow of the Royal Historical Society.
}

THE term "deaf and dumb," as commonly used in this country to include the whole of this unhappy class, is a misnomer, the only persons to whom it could properly apply being those wholly uneducated, or who cannot hear or speak, though educated or partially so. It will be thus seen that for the vast majority of these unhappy ones-for all, indeed, if properly educated-the term should be "deaf," not "deaf and dumb ;" for there is no such thing as a child born dumb because deaf. All without exception are born with voice, i.e., can produce vocal sound. It is only because of the want of a proper means of communication between deaf children and hearing persons that the former become dumb. Their brain-power, too, is the same as that of ordinary persons,--in fact, deafness alone makes them to differ.

There are two great systems of education for the "deaf and dumb," called the "German" and the "French." The former teaches language and all other branches of instruction by means of articulation and lip reading; the latter by signs and the manual alphabet, the language of signs being in an inverted order as far as English and all other European languages are concerned,-e.g., "Ball plays boy." Written characters and pictures are common to each.

The only other system of importance is called the "combined." This, as its name implies, is a combination of the "German" and "French." 
It is the object of this paper, while glancing back to the earliest times at the history of the "deaf and dumb," chiefly to trace the origin and formation of the systems before mentioned.

The earliest record known relating to the deaf and dumb is in the Book of Exodus, iv. II ; the next is in the Book of Leviticus, xix. 14 ; where it is said, "Thou shalt not curse the deaf." Would that this holy law had been observed by all nations! But we find, in the few passages relating to the deaf and dumb in other countries, that they were almost universally considered a special curse sent upon their relations, and were often destroyed to take away the reproach supposed to attach to those related to them ; frequently had terrible cruelties inflicted upon them, and at best were treated as idiots and kept in confinement. Even the master mind of Aristotle was betrayed into the error of believing the deaf and dumb incapable of producing sound and unendowed with reason. Although the utter injustice of such a theory has long since been proved, there are, unhappily, even at the present day, individuals who imagine that the deaf are physically incapable of speech, and idiocy a natural consequence of dumbness.

The common law of our own land relating to the deaf is most equitable; everything is made to depend upon the capacity of the person in each individual case ; e.g., a deaf and dumb person cannot be punished for crime, cannot make a will, administer property, be a witness on a trial, or exercise any civil right unless it can be shown that he understands the nature of the act in each case. If this is proved to the satisfaction of the court, if he appears to have sufficient knowledge and appreciation of the consequences of such acts, then he is treated like any other person-must bear the responsibilities and has a right to the privileges of every Englishman in the possession of his faculties.

Under the Roman law, spendthrifts and the deaf and dumb -being unable to administer their property-were placed under a curator, who had to see that they and their estates were properly cared for. 
For centuries after scarce a mention is made of the deaf and dumb ; and of the possibility of their instruction no idea seems to have been formed until the year A.D. 685, when we learn that the then Archbishop of York, St. John of Beverley, taught a deaf and dumb person to speak-a poor beggar whom he passed daily.

This he is believed to have done much as practised now in the "German" system schools, by getting the pupil's attention, by making him imitate the motions of the lips and vocal organs of the teacher, and so produce articulate sounds.

This appears to be the only recorded case until eight hundred years later, when in the fifteenth century Rudolphus Agricola, a native of Gröningen, in his posthumous work "De Inventione Dialecticæ," relates having seen a person deaf and dumb from infancy, who had learned writing and was able to express all his ideas by that means. Mention is next made by Rabelais of a young Italian named Nello di Gabrielis who, though deaf, could understand all that was said to him by merely watching the lips of the speaker. Why the witty French writer should have thought fit to divert his pen from its usual coarsely humorous and satiric channels in order to describe a case of this nature is difficult to imagine, unless it was a cover under which he managed to attack, in his usual scathing though often obscure manner, religious opinions and customs distasteful to himself.

In the eleventh century Jerome Cardan, a learned but erratic Italian, "took," we are told, " the subject into serious consideration ;" and it appears that he thought out most of the points now in use in the "French" system; but, being a highly unpractical man, no good came of his labours in this direction, unless his views were afterwards copied and passed off as original,-which is quite possible.

We now pass to Spain, where, about the same time as Cardan, lived a Benedictine monk, Pedro Ponce-or Pedro Ponce de Léon, as he is more often called,-who taught two brothers and a sister of the Constable of Arragon; and after this a son of the Governor of Castille; all these being toto 
congenitals. He left in manuscript deposited in the library of his monastery the methods he adopted in the education of his pupils; and there is good reason for believing that Jean Pablo Bonet, another Spanish priest, who forty years later published in 1620 a work on the deaf and dumb, derived much of his knowledge from Ponce, as he taught another member of the same house of Castille, and must have had much opportunity for conversation with his pupil's relations, who would have remembered Ponce and his system. Also it is not improbable that Bonet had access to Ponce's manuscript. Bonet's book was much used by De l'Epée, though his system seems to have been the "Combined." This is one out of many instances that could be given to show how often the "Combined" has degenerated into the "French" system.

It is a curious fact that one and the same idea, before unheard of, will spring up, as it were spontaneously, in many parts of the world at the same time. Philosophers have in vain tried to account for this most remarkable phenomenon. Take one instance well known to all-the electric telegraphit is a point that will be disputed to all time who first invented it. The truth appears to be that somewhat of the same idea came into many minds at the same time. Our present telegraph, as now in use, is the product of many minds. So also in the question with whom should rest the credit of having first invented a system of education for the deaf. Here again the same thought seems to have been engendered in many minds at the same time. During Bonet's life, and for a hundred years after, in Italy, France, Great Britain, Switzerland, the Low Countries, and Germany, persons were found, most of whom, in all honesty, believed themselves the inventors of a hitherto absolutely unknown science-the science of educating the deaf.

In England John Bulwer published the first work on the subject in 1644, entitled "Philocophus, or the Deafe and Dumbe Man's Friend." A few years later Wallis, Savilian Professor at Oxford, a man of great scientific knowledge, and Dr. William Holder, a clergyman of the Church of England and 
a Fellow of the Royal Society, gave their attention to the subject, and practised their theories on a few pupils ; their system was the "Combined," and from Wallis' writings Braidwood obtained most of his information. In 1680, George Dalgarno, a native of Aberdeen, published a work containing much that would be found useful and practical by the teachers of the "French" system at the present day; it is entitled "Didascalocophus." In it he printed the first manual alphabethis own invention-ever seen in this country. In 1690 , Dr. Amman, a physician, a native of Switzerland, but practising in Holland, published a work called "Surdus Loquens," believing himself the first instructor of the deaf. The book was so highly thought of that it passed through many editions, and was translated into several foreign languages. It may be said to have commenced the "German" system.

Of others who taught the deaf and dumb, or mentioned them in their writings, the following may be named :-Affinate, Fabrizio d'Acquapendente, Jean Bonifacio, Pierre de Castro, Lana Ferzi, George Sibscota, Peter Montans, Van Helmont, Kerger, George Raphel, Otho Benjamin Lasius, Arnoldi, Vanin, Rodrigue Pereire, Ernaud, Deschamps, and Henry Baker.

But, excellent as were many of the ideas given in the works before mentioned, we must pass on to the lives and teaching of three great men-Samuel Heinicke in Leipzig, the Abbé de l'Epée in Paris, and Thomas Braidwood in Edinburgh, who are justly looked upon as the founders of the systems in use at the present day, the "German," the "French," and the "Combined." The term "founders" is used, for they were not the sole inventors of these systems; nor are the systems, as now taught, in all respects identical with theirs; but each was instrumental in founding a school in which his system was carried out, and where men were trained who should carry on the work after the founders were dead and buried. It is for this that we must always associate with intense gratitude the names of Heinicke, Braidwood, and De l'Epée with the deaf Before their time every one who had taken up the subject was 
content either to let it die with him, or to leave its virtues to the precarious fortunes of writing,- not one trained others to succeed him.

De l'Epée was born A.D. I7I2, Heinicke I729, and Braidwood about the same time. The characters of the two former were widely different. De l'Epée was frank, open, generous, self-sacrificing ; Heinicke reserved, mysterious, and apparently somewhat avaricious. But it must be borne in mind that the former was a priest, without worldly cares or a family to provide for, whereas Heinicke was a poor man, who had to fight his way to obtain and keep an honourable position, and to maintain a young family. Still, Heinicke's supposed character, and the mystery he indulged in, have naturally told against the success of the system which he founded. True, it has become universal almost in Germany, has spread and is spreading far and wide over other countries, where till recently the "French" system alone was taught; has entirely superseded the latter in Holland; bids fair to do so in Italy; has advanced even into France, and is compelling unwilling attention in America and our own country; but the wide publicity given to their teaching by De l'Epée and his successor the Abbe Sicard caused the French system to be generally adopted a century before the "German."

And this leads to a point of great importance to us in this country; a point about which there has been written in America more error than on any other relating to the deaf. It has been asserted that the "German" system was tried in England, failed, and was discontinued. The origin of this error is not far to seek, but the mischief it has done is incalculable. Gallaudet, the noble "apostle of deaf mutes," as he is often called in America, desiring early in this century to learn how to instruct the deaf and dumb, came to this country and made the acquaintance of Dr. Watson, the first head of the London Institution. The "Combined" method was here in use, for Watson had learned under Braidwood. But Gallaudet met with difficulties ; Watson wished him to do certain things which he objected to, and he left without having mastered the 
method of teaching employed, and so it came to pass that Gallaudet, knowing that Watson taught articulation, but knowing no more, went away with the notion which has prevailed in America almost to the present day, that Watson was teaching on the "German" system. He took this for granted because articulation was taught. He failed to appreciate, as so many do now, the cardinal difference of these systems. It is this, that under the "Combined " method, a system of signs is the basis of instruction, articulation being only an accomplishment, just as modern languages were taught in our old public schools, with the result we all know. Those thus taught never feel at home in speaking, find great difficulty in making themselves understood, and so soon cease to try.

The same result is observed with those taught on the "Combined" method. They find people outside their schools unable to understand them, and so they, too, soon cease to make the attempt.

Thus articulation is brought into discredit, not as being in any way unsuited to the deaf, but because it has been treated as an accomplishment. Indeed, the case of those thus educated practically differs but little from the results obtained under the "French" system, but that little is not in favour of the "Combined" method, for the pupils so taught are taken away from the rest to learn articulation, it may be for half an hour a day more or less. What are the constant remarks of the teachers? Why, that the "articulation pupils are behind the others." And no wonder, for whatever takes the pupil away from his companions, be it articulation, drawing, Latin, or any other things foreign to the ordinary work of his class, must have the effect of making him show to disadvantage with his class-mates, whose attention and time have not been disturbed. But it may be argued, "Could not more time be given to articulation?" This would be of no avail, so long as signs constitute the basis of instruction, for it has been found that so long will the pupils think in them rather than in articulation. In that case no good result would be gained, because articulation would be but a foreign language 
in which ease enough to be pleasant or useful would rarely be gained, an annoyance very often, a task, and ever lead to disappointment.

A "foreign language"! Is it not startling to hear English spoken of thus in the case of English children? Yet such is English to those taught on the "French" and "Combined" methods. It is a foreign language to them, as we are constantly reminded by the teachers of those systems. Let us see whether such is the case with those taught on the "German" system.

Here, to begin with, there is no inverted order; and as those taught thereon have no other medium for thought than the English language, there is certainly no reason, theoretically, why their language should not be as pure as that of hearing children. This is scarcely the case at first, yet it is found that such a result is reached before leaving school, and is not lost afterwards.

There are upwards of a hundred schools for the deaf in Germany and (some of course purer than others, but still) all on this system. And it has been found, as one might imagine from so practical a nation as the German, that the system in universal use in that country is best fitted to enable the deaf to fight their way in the world and become useful and independent members of society. That such is the case, that they use speech as the means of every-day intercourse with those they come in contact with, is evident to any one who has sought out the old pupils in after life, those only being unable to communicate readily who have been educated in institutions where a certain amount of signs had been allowed. It has been proved that just in proportion as signs are allowed in schools, so those thus taught therein are less able to use speech in after life.

In conclusion the evidence on this subject points to the necessity of "French" system schools for the weak in intellect, and the very few whose speech, had they been hearing persons, would have been scarcely intelligible. All others should be educated on the "German" system. And it 
should be borne in mind that it is for the poor that education on this system is so especially desirable. Important as it is to all, to the poor the gift of speech is of intense value, enabling them to make themselves understood by the world at large.

There are about 20,000 deaf and dumb in this country. Of these only about half have received any education at all which shows the appalling number of 10,000 wholly uneducated, not knowing right from wrong, in this land of boasted civilization and intellectual development. As the life of the deaf mute is of so short an average duration, it follows that a larger proportion than of hearing persons are of a right school age, and it has been calculated that there are 2,000 such receiving no instruction whatever, and only 100 are being taught on the best method. To remedy this, the first necessity appears to be a supply of teachers trained on the "German" system, as it is so little known in this country. To this end an effort is being made to establish a training college under the direction of an English gentleman who has been specially trained for this purpose in Germany.

It is also rumoured that a society is about to be started in order to spread the blessings of education to the deaf both rich and poor, throughout this kingdom, and that this will be done by establishing small day schools throughout the country on the "German" system. 